\title{
ANALISA KADAR AIR DAN UJI ORGANOLEPTIK PADA IKAN MUJAIR (Oreochcromis mossambicus) DI PASAR BRESEHATI
}

\author{
Musa Yapen, Bertie E. Kaseger, Nurmeilita Taher \\ Fakultas Perikanan dan Ilmu Kelautan, Universitas Sam Ratulangi, Manado, Sulawesi Utara.
}

\begin{abstract}
ABSTRAK
Ikan mujair (Oreochromis mossambicus) termasuk jenis ikan yang bernilai ekonomis tinggi dan biasanya dipasarkan dalam bentuk segar. Penelitian ini bertujuan untuk menganalisa kadar air dan uji organoleptik ikan Mujair segar yang dipasarkan di pasar Bersehati Kota Manado. Metode penelitian yang digunakan adalah metode eksperimen, yang dilakukan di Laboratorium Penanganan dan Pengolahan Hasil Perikanan, Fakultas Perikanan dan Ilmu Kelautan Universitas Sam Ratulangi. Hasil penelitian menunjukkan bahwa Nilai Rata-rata kadar air ikan Mujair pada jam 09:00 76,45\% dan pada jam 15:00 beratnya konstan menjadi 76,86\% sehingga pada jam 21:00 WITA terjadi peningkatan kadar air ikan Mujair 77,88\%. Dan nilai Rata-rata kadar air pada jam 09:00, 0,29 \% dan pada jam 15:00 WITA terjadi peningkatan 1,02\% sedangkan pada jam 21:00 terjadi peningkatan kadar air ikan Mujair 1,31\%. Hasil uji organoleptik Ikan Mujair pada kriteria Mata, Insang, Daging dan perut, Bau, Tekstur. Menunjukkan bahwa pada jam 09:00 WITA kedua jenis ikan Mujair masih dalam keadaan segar, dan pada jam 15:00 WITA terjadinya perubahan suhu yang kurang baik. Sehingga pada jam 21:00 WITA terjadinya penurunan tingkat kesegaran ikan yang sangat signifikan. Berdasarkan hasil analisa kadar air dan uji organoleptik ikan Mujair yang dipasarkan di Pasar Bersehati Kota Manado menunjukkan jenis ikan ini dalam keadaan yang masih baik (segar).
\end{abstract}

Kata kunci: Ikan Mujair, Oreochcromis mossambicus, kadar air, uji organoleptik, pasar tradisional.

\section{PENDAHULUAN}

Di Indonesia dan beberapa Negara seperti, Filipina, Malaysia ikan menyumbang $60-70 \%$ dari kebutuhan protein hewani masyarakat (Anonymous, 1988 dalam Berhimpon, 1997). Ikan merupakan salah satu sumber makanan yang sangat dibutuhkan oleh manusia, hal ini di karenakan ikan mengandung protein yang cukup tinggi (Afrianto dan Liviawaty, 1989). Selain itu ikan juga di kenal memiliki kandungan EPA dan DHA (omega-3) yang dapat membantu perkembangan otak dan dapat mencegah terjadinya beberapa penyakit seperti jantung.

Kelemahan daging ikan mujair adalah lebih mudah busuk (perishable), setelah ikan mati akan mengalami perubahanperubahan sampai akhirnya ikan busuk ditolak sebagai makanan. Perubahan-perubahan tersebut umumnya disebabkan oleh adanya aktifitas enzim yang berasal dari jaringan ikan itu sendiri maupun enzim yang berasal dari bakteri. Kerusakan atau kebusukan oleh mikroorganisme disebabkan oleh terdegradasinya protein, lemak dan glikogen menjadi senyawa-senyawa yang lebih sederhana.
Enzim mempunyai pH optimum pada saat aktivitas dan reaksinya mencapai maksimum. Penurunan $\mathrm{pH}$ setelah ikan mati menambah aktivitas enzim dalam proses glikolisis. Kegiatan enzim paling aktif adalah setelah ikan mati dimana terdapat suasana agak asam, sedangkan pada suasana alkalis pada kadar air terbatas kegiatan enzim agak lambat. Pada ikan yang masih hidup nilai $\mathrm{pH}$ mencapai 7,0 dan setelah ikan tersebut mati, $\mathrm{pH}$ mencapai 5,8 sampai 6,2 yaitu pada saat mana terjadi kekakuan atau rigormortis (Suwetja, 1993). Menurunnya $\mathrm{pH}$ pada daging ikan tersebut diakibatkan karena sudah tidak ada lagi oksigen yang masuk ke dalam sel- sel daging, itu sebabnya sintesa glikogen dan glikolisis akan berlangsung secara anaerob, sehingga menghasilkan asam laktat dan ATP. Asam laktat inilah yang menyebabkan turunnya $\mathrm{pH}$ daging.

Ikan mujair mudah mengalami pembusukan maka faktor utama harus mendapatkan perhatian pada hasil perikanan sebelum di konsumsi adalah dengan cara mempertahankan nilai kesegaran ikan. Untuk mempertahankan nilai kesegaran ikan sebaiknya dengan cara menghambat atau menghentikan kegiatan enzim dan mikroorganisme yang 
terdapat pada tubuh ikan serta menghindari kontaminasi. Pada waktu ikan masih hidup, insang dan isi perutnya sudah memiliki bakteri. Bakteri ini akan bertambah berlipat ganda pada tingkat akhir autolisis (Ilyas, 1983).

Salah satu cara untuk mempertahankan nilai kesegaran ikan mujair di pasar Bersehati adalah dengan cara penanganan. Penanganan ikan setelah penangkapan atau pemanenan memegang peranan penting untuk memperoleh nilai jual ikan yang maksimal. Proses pemasaran ikan mujair sampai ke tangan konsumen akhir (untuk dikonsumsi), biasanya memerlukan waktu 1-2 hari maka untuk mempertahankan nilai kesegaran dan nilai jual ikan mujair tersebut perlu dilakukan penaganan selama pemasaran (Junianto, 2003).

\section{METODOLOGI PENELITIAN}

Metode yang digunakan dalam penelitian ini adalah metode dengan cara mengumpulkan, menyelidiki, dan menafsirkan data secara umum sebagai apa adanya yang tersedia (Anonimous, 1974). Data kadar air diperoleh melalui analisa kadar air dengan metode oven, sedangkan data organoleptik diperoleh melalui penilaian panelis.

\section{Bahan dan Alat}

Bahan yang digunakan dalam penelitian ini adalah: ikan Mujair ,Air bersih dan es batu. Alat yang digunakan untuk analisa kadar air yaitu: cawan porselin, desikator, wadah, pisau, pinset, timbangan analitik, thermometer, Alat pengering berupa oven. Sedangkan alat untuk pengujian organoleptik antara lain piring, lembar score sheet alat tulis, dan tissue.

\section{Tata Laksana Penelitian}

Pengambilan sampel ikan segar pada Pukul 09:00, 15:00 dan 21:00 WITA, berjumlah 21 ekor ikan Mujair segar di pasar Bersehati. Ikan tersebut dibawa ke Laboratorium Penanganan dan Pengolahan Hasil Perikanan FPIK UNSRAT untuk analisa kadar air dan uji organoleptik.

Tata laksana Penelitian yang digunakan dalam penelitian ini adalah pengambilan sampel yang terdiri dari :

$$
\begin{aligned}
& \text { A : Jam } 09.00 \text { WITA } \\
& \text { B : Jam 15.00 WITA } \\
& \text { C : Jam 21.00 WITA }
\end{aligned}
$$

Ulangan yang digunakan dalam penelitian ini adalah sebanyak enam kali. Untuk analisa organoleptik dan dua kali untuk analisa kadar air.

Analisa Kadar Air (Sudarmadji, dkk., 1997)

1. Cawan porselin dan tutupnya dicuci bersih dan kemudian dikeringkan dalam oven pada suhu $100-105^{\circ} \mathrm{C}$ selama satu jam.

2. Dengan tang penjepit cawan porselin dikeluarkan dari oven dan dimasukan dalam desikator selama 30 menit, cawan porselin yang telah dingin kemudian ditimbang (A).

3. Sampai ditimbang dengan cawan porselin tersebut sebanyak \pm 2 gram (B)

4. Cawan porselin yang berisi sampel kemudian dimasukan kembali dalam oven pada suhu $100-105^{\circ} \mathrm{C}$ selama 24 jam.

5. Kemudian cawan porselin tersebut dikeluarkan dengan tang penjepit lalu dimasukan ke dalam desikator selama 30 menit, lalu ditimbang $(\mathrm{C})$

6. Perhitungan: Kadar air $=\frac{\mathrm{B}-\mathrm{C}}{\mathrm{B}-\mathrm{A}} \times 100 \%$

\section{Uji Organoleptik ( SNI 1991)}

Pengujian organoleptik yaitu pengujian terhadap kondisi fisik ikan segar pada jenis ikan yang ada di pasar Bersehati dengan menggunakan penilaian score sheet ikan segar (SNI 01-2346-1991), dimana pengujian tersebut bertujuan untuk mengetahui tingkat kesegaran ikan dengan menggunakan indera sensori. Pengujian organoleptik dilakukan dengan menggunakan alat berupa score sheet organoleptik ikan segar. Pada score sheet menggunakan angka 1 sebagai nilai terendah dan angka 9 untuk nilai tertinggi. Pengujian organoleptik dilakukan oleh 10 orang panelis.

\section{HASIL DAN PEMBAHASAN}

\section{Uji Kadar air pada ikan Mujair}

Hasil analisa kadar air ikan Mujair segar dapat dilihat pada tabel 1 .

\begin{tabular}{|c|c|c|c|}
\hline \multirow{2}{*}{$\begin{array}{c}\text { Waktu } \\
\text { analisa }\end{array}$} & \multicolumn{2}{|c|}{ Kadar air (\%) } & \multirow{2}{*}{$\begin{array}{c}\text { Rata-rata } \\
(\%)\end{array}$} \\
\hline & 1 & 2 & \\
\hline $09.00(\mathrm{~A})$ & 77,45 & 75,69 & 76,57 \\
\hline 15.00 (B) & 76,62 & 77,10 & 76,86 \\
\hline $21.00(\mathrm{C})$ & 78,03 & 77,74 & 77,88 \\
\hline
\end{tabular}

Tabel 1. Data hasil analisa kadar air ikan Mujair (Oreochrombis mossambicus).

Berdasarkan tabel 1 tersebut dapat dilihat bahwa nilai rata-rata kadar air yang tertinggi adalah $77,88 \%$ yaitu pada waktu analisa jam 21.00 (C). Sedangkan kadar air 
terendah adalah $76,57 \%$ pada waktu analisa jam 09.00 (A). Peningkatan kadar air ikan Mujair sangat kecil yaitu dari A ke B sebesar 0,29\%, dari $\mathrm{B}$ ke $\mathrm{C}$ sebesar 1,02 \% Sedangkan dari A ke $\mathrm{C}$ sebesar $1,31 \%$. Peningkatan kadar air yang sangat kecil ini kemungkinan tidak memberikan perbedaan yang berarti terhadap perubahan mutu ikan Mujair. Persentase kadar air ikan Mujair dalam penelitian ini masih berada pada kisaran kadar air yang sesuai dengan SNI No. 01-2346-1991 yaitu kadar air ikan segar berada pada kisaran $70-80 \%$.

\section{Uji organoleptik}

\section{Mata}

Adapun hasil rata-rata uji organoleptik mata ikan Mujair segar adalah seperti pada tabel 2 .

Tabel. 2. Hubungan waktu dengan rata-rata nilai kriteria mata ikan Mujair (Oreochromis mossambius) segar.

\begin{tabular}{|c|c|}
\hline $\begin{array}{l}\text { Waktu } \\
\text { analisa }\end{array}$ & $\begin{array}{c}\text { Nilai rata-rata } \\
\text { organoleptik mata }\end{array}$ \\
\hline Jam 09.00 (A) & 8,4 \\
\hline Jam 15.00 (B) & 7,8 \\
\hline Jam $21.00(\mathrm{C})$ & 3,8 \\
\hline
\end{tabular}

Pada tabel 2 terlihat bahwa semakin lama waktu, nilai mata ikan mujair segar semakin menurun. Hal ini menunjukkan bahwa tanpa penanganan pada jam 21.00 kriteria mata ikan Mujair ditolak oleh panelis. Nilai mata tidak sesuai dengan SNI. Pengambilan sampel pada jam 09.00 dan 15.00, kriteria nilai mata ikan mujair segar masih diterima oleh panelis dan pula masih memnuhi standar SNI ikan segar, kriteria nilai mata masih sesuai sampai kira-kira jam 17.00.

\section{Insang}

Adapun hasil rata-rata uji organoleptik insang ikan Mujair segar adalah seperti pada tabel 3 .

Tabel 3. Hubungan waktu pengambilan sampel dengan rata-rata nilai insang ikan Mujair segar.

\begin{tabular}{cc}
\hline $\begin{array}{c}\text { Waktu } \\
\text { analisa }\end{array}$ & $\begin{array}{c}\text { Nilai rata-rata } \\
\text { organoleptik insang }\end{array}$ \\
\hline Jam $09.00(\mathrm{~A})$ & 7,4 \\
Jam 15.00 (B) & 7,5 \\
Jam 21.00 (C) & 3,6 \\
\hline
\end{tabular}

Pada tabel 3 terlihat bahwa semakin lama waktu, kriteria nilai insang ikan Mujair segar semakin menurun. Hal ini menunjukkan bahwa tanpa penanganan pada jam 21.00 kriteria insang ikan Mujair ditolak oleh panelis. Nilai insang ikan Mujair segar tidak memenuhi SNI. Pengambilan sampel pada jam 09.00 dan 15.00, kriteria nilai insang ikan Mujair segar masih diterima oleh panelis dan pula masih memenuhi standar SNI ikan segar masih sesuai sampai jam 15.00.

\section{Daging dan isi perut}

Adapun hasil rata-rata uji organoleptik daging dan isi perut ikan Mujair segar adalah seperti pada tabel 4 .

Tabel 4. Hubungan waktu pengambilan sampel dengan rata-rata nilai daging dan isi perut ikan Mujair segar.

\begin{tabular}{cc}
\hline $\begin{array}{c}\text { Waktu } \\
\text { analisa }\end{array}$ & $\begin{array}{c}\text { Nilai rata-rata } \\
\text { daging dan isi perut }\end{array}$ \\
\hline Jam $09.00(\mathrm{~A})$ & 8,3 \\
Jam $15.00(\mathrm{~B})$ & 7,7 \\
Jam 21.00 (C) & 3,7 \\
\hline
\end{tabular}

Pada tabel 4 terlihat bahwa semakin lama waktu, nilai daging dan isi perut ikan Mujair semakin rendah. Hal ini menunjukkan bahwa tanpa penanganan pada jam 21.00 kriteria daging dan isi perut ikan Mujair ditolak oleh para panelis. Nilai daging dan isi perut ikan Mujair segar tidak memenuhi SNI. Pengambilan sampel pada jam 09.00 dan 16.00, kriteria daging dan isi perut ikan Mujair segar masih diterima oleh panelis dan pula masih memenuhi standar SNI ikan segar. masih sesuai sampai kira-kira jam 16.00.

\section{BAU}

Adapun hasil rata-rata uji organoleptik bau ikan Mujair segar adalah seperti tabel 5.

Tabel 5. Hubungan waktu dengan rata-rata nilai bau ikan Mujair segar.

\begin{tabular}{cc}
\hline $\begin{array}{c}\text { Waktu } \\
\text { analisa }\end{array}$ & Nilai rata-rata bau \\
\hline Jam 09.00 (A) & 8,2 \\
Jam 15.00 (B) & 6,4 \\
Jam 21.00 (C) & 3,3 \\
\hline
\end{tabular}

Pada tabel 5 terlihat bahwa analisa lama waktu, nilai bau ikan Mujair segar semakin tinggi. Hal ini menunjukkan bahwa tanpa penanganan jam 21.00 kriteria bau ditolak oleh panelis. Nilai bau ikan Mujair segar tidak memenuhi SNI. Pengambilan sampel pada jam 15.00 dan 21.00, kriteria nilai bau ikan Mujair 
segar ditolak oleh panelis dan pula tidak memenuhi standar SNI ikan segar. Kriteria nilai bau tidak sesuai sampai jam 15.00 dan 21.00.

\section{TEKSTUR}

Adapun hasil rata-rata uji organoleptik tekstur ikan mujair ( Oreochromis mossambicus ) segar adalah seperti pada table 7 .

Tabel 6. Hubungan waktu dengan rata-rata nilai tekstur ikan Mujair segar.

\begin{tabular}{cc}
\hline $\begin{array}{c}\text { Waktu } \\
\text { Analisa }\end{array}$ & $\begin{array}{c}\text { Nilai rata-rata } \\
\text { tekstur }\end{array}$ \\
\hline Jam 09.00 (A) & 8,4 \\
Jam 15.00 (B) & 7,6 \\
Jam 21.00 (C) & 4,1 \\
\hline
\end{tabular}

Pada tabel 6 terlihat bahwa semakin lama waktu, nilai tekstur ikan Mujair segar semakin menurun hal ini menunjukkan bahwa tanpa penanganan pada jam 21.00 kriteria tekstur ikan Mujair ditolak oleh panelis dan tidak sesuai dengan SNI Pengambilan sampel pada jam 09 dan 15, kriteria nilai tekstur ikan mujair segar masih diterima oleh panelis dan pula masih memenuhi standar SNI ikan segar masih sesuai sampai jam 15.00.

\section{KESIMPULAN}

Berdasarkan hasil penelitian yang sudah dilakukan dapat diambil kesimpulan sebagai berikut:

1. Kadar air Ikan Mujair segar di pasar Bersehati pada pengambilan sampel jam 09.00-21.00 WITA berada pada kisaran $75,57-77,80 \%$.

2. Nilai uji organoleptik mata, insang, daging dan perut, tekstur ikan Mujair segar hingga jam 15.00 WITA masih diterima oleh panelis.
3. Nilai organ organoleptik bau ikan Mujair segar pada jam 15.00 dan 21.00 WITA ditolak oleh panelis.

\section{DAFTAR PUSTAKA}

Afrianto, E. dan Liviawaty, 1989. Pengawetan dan pengolahan ikan penerbit Kanisius, Yogyakarta.

Apriyantono, A.D. Fardiaz. N. L. Puspitasari, Sadarnawati dan S. Budiyanto, 1989. Analisis Pangan. Pusat Antar Universitas Pangan dan Gizi: IPB. Bogor.

Anggawati. A. 2001. Penanganan ikan segar. Artikel. Departemen Kelautan dan Perikanan, Jakarta.

Anonimous, 2001, Pengendalian Mutu Ikan Segar, Fakultas Perikanan dan Ilmu Kelautan UNSRAT Manado.

Berhimpon.S. 1997. Potensi industry pangan Hasil Laut di Sulawesi Utara. Fakultas Perikanan dan Ilmu Kelautan Manado.

Fardiaz, S. 1993. Analisis Mikrobilogi Pangan P.T. Raja Telur, Liberty. Yogyakarta.

Moeljanto, 1992. Pengawetan dan pengolahan Hasil Perikanan. Penebar Swadaya. Jakarta.

Suzuk. T, 1981. Fish and krill protein. processing Tecnology Applied Science Publisher Ltd., London.

Sarmanto, P. Poernomo, A., Dwisuryaningrum, Ilyas. S. 1982. Evaluasi Kandungan Protein Ikan Indonesia. Laporan Penelitian Teknologi Perikanan No. 19. Balai Penelitian Teknologi Perikanan. Jakarta.

Sugiarto, 1988. Teknik Penelitian ikan mujair CV. Simpleks Jakarta. Soekarto, S., 1991. Penilaian Organ Oleptik Untuk Industri Pangan dan Hasil Pertanian. IPB. Bogor.

Soetoyo, 1984. Pengembangbiakan Ikan di Indonesia. CV. Simpleks Jakarta

Winarno, F.G dan B. S. L. Jennie, 1982. Kerusakan Bahan Pangan dan Cara pencegaan Ghalia Indonesia. Bogo.

Zaitzev, V : Kizevett, I; Langonov, L; Makanov, T; Minder and Podsevanov, 1969. Fish curing and Processing. Publisher. Mosko 